\title{
Characterization of Nanoporous Ceramic Granules Made with Coal Fly Ash and Their Utilization in Phenol Removal from Water
}

\author{
Zhaoqian Jing \\ College of Civil Engineering, Nanjing Forestry University, Nanjing 210037, China
}

Correspondence should be addressed to Zhaoqian Jing; zqjing@yahoo.com

Received 1 December 2012; Accepted 13 February 2013

Academic Editor: Shao-Wen Cao

Copyright (C) 2013 Zhaoqian Jing. This is an open access article distributed under the Creative Commons Attribution License, which permits unrestricted use, distribution, and reproduction in any medium, provided the original work is properly cited.

Coal fly ash has been evaluated as low-cost material for pollutants adsorption. But powdered fly ash is difficult to be separated from the adsorbate and solution after saturation. When it is made into granules, this problem can be solved. Granules with uniform diameter of $6 \mathrm{~mm}$ were prepared and used as adsorbents for phenol removal from aqueous solution. The physical and chemical characteristics of the granules were investigated. The data indicated that the granules were abundant with nanosize pores of $9.8 \mathrm{~nm}$ on average. The specific surface area and porosity reached $130.5 \mathrm{~m}^{2} / \mathrm{g}$ and $60.1 \%$, respectively. The main components in the granules were $\mathrm{SiO}_{2}, \mathrm{Al}_{2} \mathrm{O}_{3}, \mathrm{MgO}, \mathrm{Fe}_{2} \mathrm{O}_{3}, \mathrm{CaO}, \mathrm{K}_{2} \mathrm{O}$, and unburned carbon. The adsorption batch experiments showed that this granular material was an efficient adsorbent for phenol removal. Phenol adsorption on the granules was mainly influenced by dosage and contact time. Increase in the dosage could enhance phenol adsorption effectively. More than $90 \%$ phenol could be removed under normal temperature and neutral $\mathrm{pH}$ with initial concentration of $100 \mathrm{mg} / \mathrm{L}$, contact time of $90 \mathrm{~min}$, and dosage of $140 \mathrm{~g} / \mathrm{L}$. The adsorption of phenol on the granules was spontaneous and complied well with the pseudo-second-order model and Langmuir isotherm model.

\section{Introduction}

Coal fly ash is byproduct from the burning process of coal in fired burning plants and other industries with coal as fuel. It is usually taken as solid industrial waste in many countries and places. The annual production of coal fly ash has continued to increase in recent years. Disposal of it usually consumes large quantities of land and water [1]. Coal fly ash is generally composed of $\mathrm{SiO}_{2}, \mathrm{Al}_{2} \mathrm{O}_{3}, \mathrm{CaO}, \mathrm{Fe}_{2} \mathrm{O}_{3}, \mathrm{MgO}$, and unburned carbon. It can be used not only as an additive in construction industry [2] but also as cheap media for soil amelioration [3] and adsorbents for pollutants removal [4].

Phenol is an important raw material or product of some industries such as coal tar, gasoline, plastic, pesticide, and steel production. It can be combined with other pollutants as phenolic compounds. Moreover, phenol is always dissolved in water with high solubility, but lesser amount of it can produce unpleasant odor and cause chronic toxic effects to human being, animals, and plants [5]. Many countries have listed phenol as one kind of priority pollutants and set strict limits for it in surface water and wastewater discharge [6]. Complete removal or in some cases reduction of it to an acceptable concentration has become a major challenge for environment protection.

Because of the toxic characteristics, it is very difficult for phenol to be biodegraded directly. The regular treatment methods for water containing phenol are flocculation, solvent extraction, adsorption, advanced oxidation, and so forth. Among these processes, adsorption has been taken as an effective separation process for phenol. Although activated carbon is widely used as adsorbent for phenol removal from water, it has the disadvantage of high-cost and complex regeneration. The development of potential low-cost adsorbents with high adsorption capacity is essential for phenol removal. In recent years, many materials such as synthetic resin [7], green macro alga [8], and bagasse fly ash [9] have been used in phenol removal from aqueous solution. Some researchers have studied the removal of phenol and its analogs from water 
TABLE 1: Physical indexes of the granules acquired by mercury porosimeter.

\begin{tabular}{lccccccc}
\hline Index & $V_{\mathrm{ti}}(\mathrm{mL} / \mathrm{g})$ & $A_{t}\left(\mathrm{~m}^{2} / \mathrm{g}\right)$ & $R_{\mathrm{mv}}(\mathrm{nm})$ & $R_{\mathrm{ma}}(\mathrm{nm})$ & $R_{a}(\mathrm{~nm})$ & $D_{a}(\mathrm{~g} / \mathrm{mL})$ & Porosity $(\%)$ \\
\hline Value & 0.33 & 66.8 & 14.7 & 6.0 & 9.8 & 4.63 & 60.1 \\
\hline
\end{tabular}

with coal fly ash [10]. But powdered fly ash is difficult to be separated from the adsorbed phenol and solution. When it is used to remove phenol from water, additional coagulation and sedimentation measures are usually needed.

In this study, coal fly ash was used to produce composite ceramic granules with high porosity and specific surface area. The physical characteristics and chemical composition of the granules were studied. The granules were used as adsorbents for phenol removal from water. Effects of various parameters such as adsorbents dosage, contact time, and temperature were studied to optimize the adsorption parameters. Kinetics, thermodynamics, and isotherm studies were also carried out to illustrate the adsorption process of phenol onto the ceramic granules.

\section{Material and Methods}

2.1. Granules Preparation. Coal fly ash was taken from a fired burning power plant utilizing coal as fuel in Huludao, Liaoning Province of China. 51\% fly ash, 39\% clay, and 10\% diatomite (in weight) were mixed after crushing and screening. The mixture was used to produce spherical granules of certain diameter with the aid of sodium silicate in a granulator. After being dried at $383 \mathrm{~K}$ with a baking furnace, the raw granules were calcined for 2 hours at $723 \mathrm{~K}$ in an incinerator [11]. The finished granules were finally produced. In the preparation process, the diameter of the granules could be accurately controlled. Granules with uniform diameter of $6 \mathrm{~mm}$ were used as adsorbent to remove phenol from aqueous solution in this study.

2.2. Characterization of the Granules. Since adsorption is an interface phenomenon, pore area and distribution in the granules are vital for the adsorption process. This material was studied firstly with scanning electron microscope (SEM, Quanta 200, FEI, Holland) to ascertain the external and sectional structure of the granules. A mercury porosimeter (Autopore 9500, Micromeritics, USA) was used to characterize the granules in terms of porosity, total pore area, pore radius, and so on. It is capable of generating a pressure up to 60,000 psi to detect the main indexes of meso- to macropores [12]. The granules were also analyzed with energy dispersive X-ray spectrometry (EDS, GENESIS, EDAX, USA) to investigate the main compositions [13].

2.3. Adsorption Experiments. The batch studies were conducted by dosing the granules into aqueous solution with certain initial phenol concentration prepared in the laboratory. The $\mathrm{pH}$ of the solutions was controlled around 7.0 with $1 \mathrm{~mol} / \mathrm{L}$ solutions of $\mathrm{HCl}$ or $\mathrm{NaOH}$. The samples were stirred in a temperature-controlled oscillator at a constant speed of $180 \mathrm{rpm}$. After some time, the supernatant was withdrawn and filtered through $0.45 \mu \mathrm{m}$ membrane filter. Residual phenol concentration was analyzed with the method of spectrophotometry [14]. The effect of operation parameters such as dosage, contact time, and temperature on phenol removal was investigated. The adsorption kinetics, thermodynamics parameters, and isotherm model were also studied.

The removal percentage of phenol $(\eta)$ and adsorption capacity $q(\mathrm{mg} / \mathrm{g})$ were calculated using the following equations:

$$
\begin{gathered}
\eta(\%)=\frac{C_{0}-C}{C_{0}} \times 100, \\
q=\frac{\left(C_{0}-C\right) V}{w},
\end{gathered}
$$

where $C_{0}$ is the initial phenol concentration $(\mathrm{mg} / \mathrm{L}), C$ is phenol concentration $(\mathrm{mg} / \mathrm{L})$ after adsorption, $V$ is the volume of the solution (L), and $w$ is the mass of the granules (g).

\section{Results and Discussion}

3.1. SEM Characterization. The shape of materials, surface texture, and even particle distribution can be observed and analyzed by scanning electron microscope $[15,16]$. SEM pictures of the external and sectional view of the composite granules are shown in Figure 1. It can be seen that this kind of ceramic granules had many drapes and pores in the surface. Some pores even penetrated into the internal part. The section plane showed typical laminated and layered structure in the granules, which amplified the specific surface area of this material and favored pollutants adsorption into the inner positions of this material.

3.2. Porous Characterization. Table 1 contains the data for the granules with the mercury intrusion method in terms of the total intrusion volume $\left(V_{\mathrm{ti}}\right)$, total pore area $\left(A_{t}\right)$, median pore radius (volume, $R_{\mathrm{mv}}$ ), median pore radius (area, $R_{\mathrm{ma}}$ ), average pore radius $\left(2 \mathrm{~V} / \mathrm{A}, R_{a}\right)$, apparent (skeletal) density $\left(D_{a}\right)$, and porosity. The average pore radius in the granules was $9.8 \mathrm{~nm}$. The total pore area, porosity, and apparent (skeletal) density of the granules reached $66.8 \mathrm{~m}^{2} / \mathrm{g}, 60.1 \%$, and $4.63 \mathrm{~g} / \mathrm{mL}$, respectively. The relationship between pore radius and incremental pore volume is shown in Figure 2. The data indicated that the radius of meso- to macropores was in the wide range of $1.5 \mathrm{~nm}$ to $45300 \mathrm{~nm}$. The peak of nanopores distribution was located at $10.5 \mathrm{~nm}$ with the incremental pore volume of $0.03289 \mathrm{~mL} / \mathrm{g}$, amounting to about $10 \%$ of the total intrusion volume. The pores with radius under $10 \mathrm{~nm}, 50 \mathrm{~nm}$, and $100 \mathrm{~nm}$ accounted for $35.1 \%$, $79.2 \%$, and $91.4 \%$, respectively. The proportion of pores with radius above $100 \mathrm{~nm}$ was only $8.6 \%$. These data indicated that the granular material was a kind of nanosize porous media 


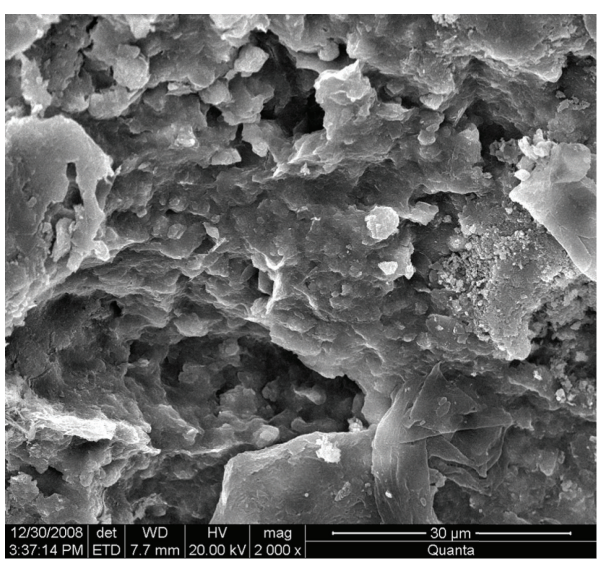

(a)

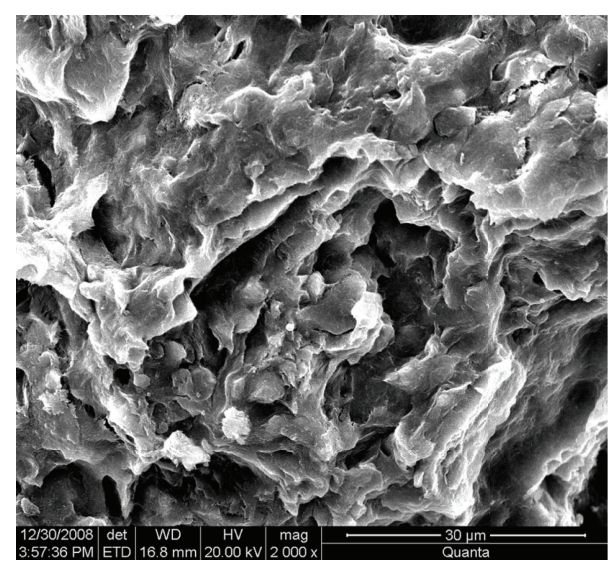

(b)

FIgURE 1: Typical SEM photographs of the ceramic granules: (a) external; (b) sectional.

TABLE 2: Main elements composition of the granules.

\begin{tabular}{lcccccccc}
\hline Main elements & $\mathrm{O}$ & $\mathrm{Si}$ & $\mathrm{C}$ & $\mathrm{Al}$ & $\mathrm{Mg}$ & $\mathrm{Fe}$ & $\mathrm{Ca}$ & $\mathrm{K}$ \\
\hline Mass (\%) & 55.94 & 17.51 & 9.97 & 4.83 & 3.2 & 2.69 & 2.04 & 1.06 \\
\hline \multicolumn{7}{c}{ Trace elements composition of the granules. } \\
\hline Trace elements & $\mathrm{Cl}$ & $\mathrm{Na}$ & $\mathrm{S}$ & $\mathrm{Ti}$ & $\mathrm{Se}$ & $\mathrm{Zn}$ & $\mathrm{Mn}$ & $\mathrm{Cu}$ \\
\hline Mass (\%) & 0.89 & 0.67 & 0.4 & 0.35 & 0.3 & 0.07 & 0.05 & 0.03 \\
\hline
\end{tabular}

with high porosity and specific surface area, which were vital parameters in the utilization as adsorbent.

3.3. Chemical Composition. As determined by EDS (Table 2), the predominant elements were $\mathrm{O}, \mathrm{Si}, \mathrm{C}, \mathrm{Al}, \mathrm{Mg}, \mathrm{Fe}, \mathrm{Ca}$, and $\mathrm{K}$, which amounted to $97.24 \%$ in total. There were also other minor elements of $\mathrm{Cl}, \mathrm{Na}, \mathrm{S}, \mathrm{Ti}, \mathrm{Se}, \mathrm{Zn}, \mathrm{Mn}$, and $\mathrm{Cu}$. Element composition of carbon accounted for $9.97 \%$ (mass fraction). This is significant since it has been shown that carbon and its compounds can significantly increase the porosity and total pore area of ceramic granules made of fly ash $[17,18]$. According to the elements composition, the chemical oxides' components in the granules were calculated. The main oxides were $\mathrm{SiO}_{2}$ (37.47\%), $\mathrm{Al}_{2} \mathrm{O}_{3}(9.13 \%), \mathrm{MgO}$ (5.31\%), $\mathrm{Fe}_{2} \mathrm{O}_{3}$ (3.46\%), $\mathrm{CaO}(2.86 \%)$, and $\mathrm{K}_{2} \mathrm{O}(1.28 \%)$.

3.4. Effect of Dosage on Phenol Adsorption. The effect of granules dosage on phenol adsorption percentage $(\eta)$ and adsorption capacity $(q)$ was investigated by varying the dosage from $20 \mathrm{~g} / \mathrm{L}$ to $300 \mathrm{~g} / \mathrm{L}$ at $\mathrm{pH} 7.0$ and $288 \mathrm{~K}$ with initial phenol concentration of $100 \mathrm{mg} / \mathrm{L}$ and contact time of $60 \mathrm{~min}$. The increase in dosage supplied more active sites at the surface and the internal structures of the granules and resulted in obvious rise in the phenol adsorption. As shown in Figure 3, with the dosage increasing from $20 \mathrm{~g} / \mathrm{L}$ to $300 \mathrm{~g} / \mathrm{L}$, the removal percentage of phenol with initial concentration of $100 \mathrm{mg} / \mathrm{L}$ increased obviously from $51.4 \%$ to $100 \%$. So it was feasible to remove phenol completely with sufficient granules dosage. At $140 \mathrm{~g} / \mathrm{L}$ dosage, nearly $90 \%$ of phenol was removed from water.

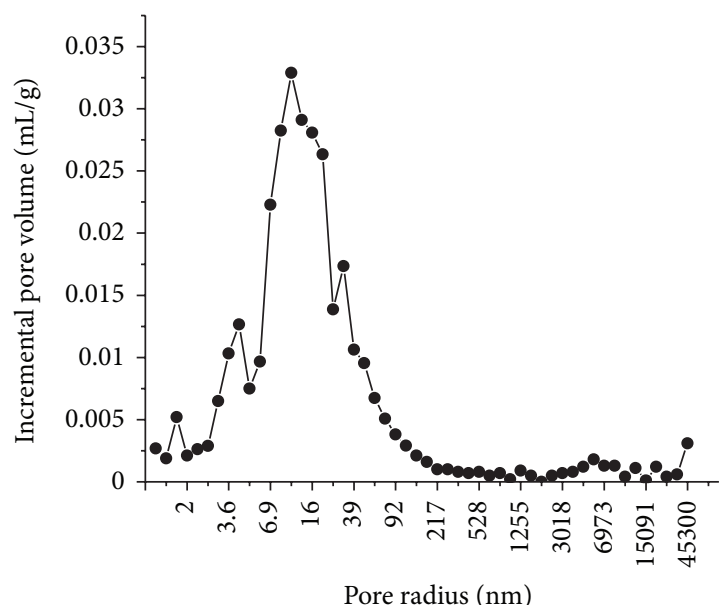

FIGURE 2: Distribution of pore size in the granules.

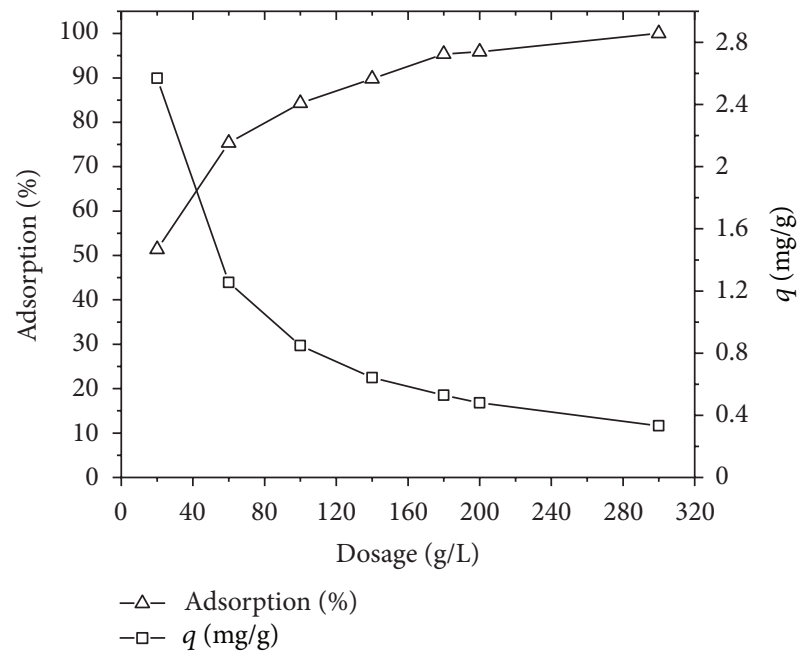

FIGURE 3: Effect of dosage on phenol removal. pH: 7.0; temperature: $288 \mathrm{~K}$; initial concentration: $100 \mathrm{mg} / \mathrm{L}$; contact time: $60 \mathrm{~min}$. 


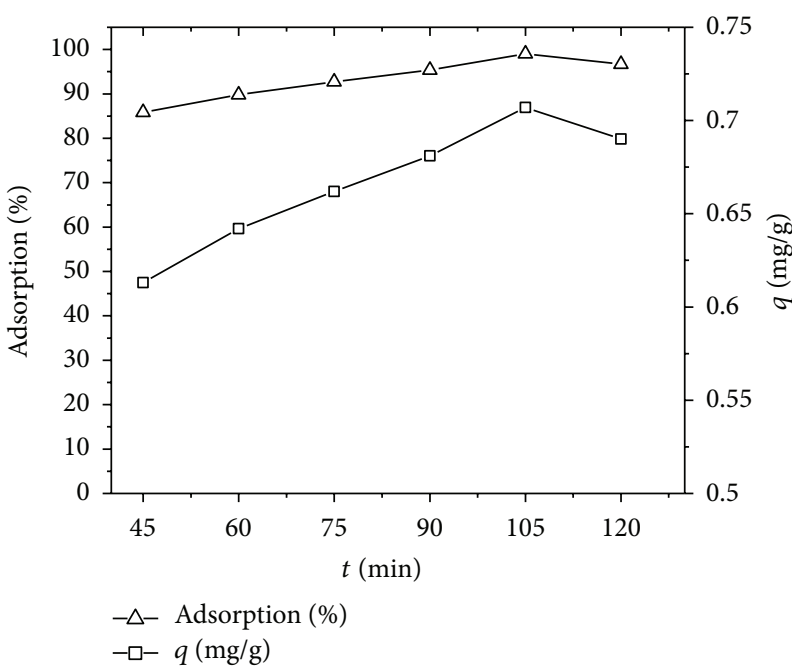

(a)

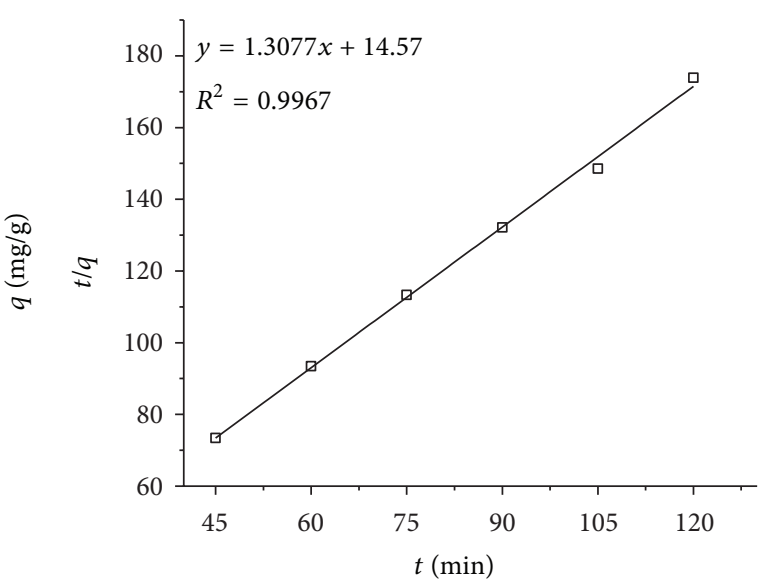

(b)

FIGURE 4: Effect of contact time on phenol adsorption: (a) adsorption percentage and capacity variation with time; (b) pseudo-second-order kinetic model. pH: 7.0; dosage: $140 \mathrm{~g} / \mathrm{L}$; temperature: $303 \mathrm{~K}$; initial concentration: $100 \mathrm{mg} / \mathrm{L}$.

It can also be seen that the adsorption capacity declined obviously with dosage increase. The adsorption capacity at $300 \mathrm{~g} / \mathrm{L}$ dosage was only $13.0 \%$ of that at $20 \mathrm{~g} / \mathrm{L}$ dosage. This indicated that the adsorption capacity could not be fully utilized at high-dosage operations. Consequently the granules after adsorption at high dosage could be reused at low-dosage operations.

3.5. Effect of Contact Time and Adsorption Kinetics. The effect of contact time on phenol adsorption was carried out to ascertain the equilibrium point and adsorption kinetics at $\mathrm{pH} 7$ and $303 \mathrm{~K}$ with the granules dosage of $140 \mathrm{mg} / \mathrm{L}$. Figure 4(a) shows phenol adsorption variation versus contact time. Before $105 \mathrm{~min}$, there were enough vacant adsorption sites on the granules, and phenol adsorption almost increased linearly with contact time. Phenol removal rose from $85.9 \%$ to $99.0 \%$ with contact time increasing from $45 \mathrm{~min}$ to $105 \mathrm{~min}$, indicating that contact time was a vital parameter for phenol adsorption on the granular material. But it can also be noticed that overlong contact time was not helpful when the adsorption of phenol attained equilibrium between the solution and the granules after $105 \mathrm{~min}$ [19]. Phenol removal percentage was maintained above $95 \%$ with contact time in the range $90-105 \mathrm{~min}$. Subsequent experiments were done with adsorption time of $90 \mathrm{~min}$, which was considered as approximately sufficient for phenol removal from water with the granules.

There are several kinetics models for substances adsorption such as the first-order kinetic model, pseudo-secondorder kinetic model, and an intraparticle diffusion kinetic model [20]. The adsorption of phenol on the granular material had the characteristics of both physisorption and chemisorption [21]. Consequently, the pseudo-second-order model might be more suitable for phenol adsorption on the granules [22].
TABLE 3: Main thermodynamic parameters variation at different temperatures.

\begin{tabular}{lccc}
\hline$T(\mathrm{~K})$ & $\Delta G^{\circ}(\mathrm{kJ} / \mathrm{mol})$ & $\Delta H^{\circ}(\mathrm{kJ} / \mathrm{mol})$ & $\Delta S^{\circ}(\mathrm{J} / \mathrm{mol} \mathrm{K})$ \\
\hline 288 & -9.93 & & \\
298 & -10.78 & & \\
303 & -11.20 & 14.42 & 84.56 \\
308 & -11.62 & & \\
318 & -12.47 & & \\
\hline
\end{tabular}

The pseudo-second-order model can be expressed using

$$
\frac{t}{q_{t}}=\frac{1}{k_{2} q_{e}^{2}}+\frac{1}{q_{e}} t,
$$

where $q_{e}$ is the equilibrium adsorption capacity (mg/g), $q_{t}$ is the amount of phenol adsorbed at time $t$ (min), and $k_{2}$ is the rate constant of pseudo-second-order adsorption $(\mathrm{g} /(\mathrm{mg} \min ))$.

$t / q_{t}$ against $t$ for the pseudo-second-order model is shown in Figure 4(b). The correlation coefficient value $\left(R^{2}\right)$ reached 0.9967 , implying that the pseudo-second-order model was appropriate for phenol adsorption onto the granular material.

3.6. Effect of Temperature on Phenol Adsorption. The effect of temperature on phenol adsorption was investigated with the operation temperature ranging from $288 \mathrm{~K}$ to $318 \mathrm{~K}$ with initial phenol concentration of $100 \mathrm{mg} / \mathrm{L}$, contact time of $90 \mathrm{~min}$ and solution $\mathrm{pH}$ of 7.0. Figure 5(a) shows the changes of equilibrium concentration $\left(C_{e}\right)$ and adsorption capacity $\left(q_{e}\right)$ under different temperatures. With the increase in temperature from $288 \mathrm{~K}$ to $318 \mathrm{~K}, C_{e}$ decreased from $10.18 \mathrm{mg} / \mathrm{L}$ to $5.97 \mathrm{mg} / \mathrm{L}$, whereas $q_{e}$ increased slightly from $0.642 \mathrm{mg} / \mathrm{g}$ to $0.672 \mathrm{mg} / \mathrm{g}$. Phenol removal percentage and adsorption 


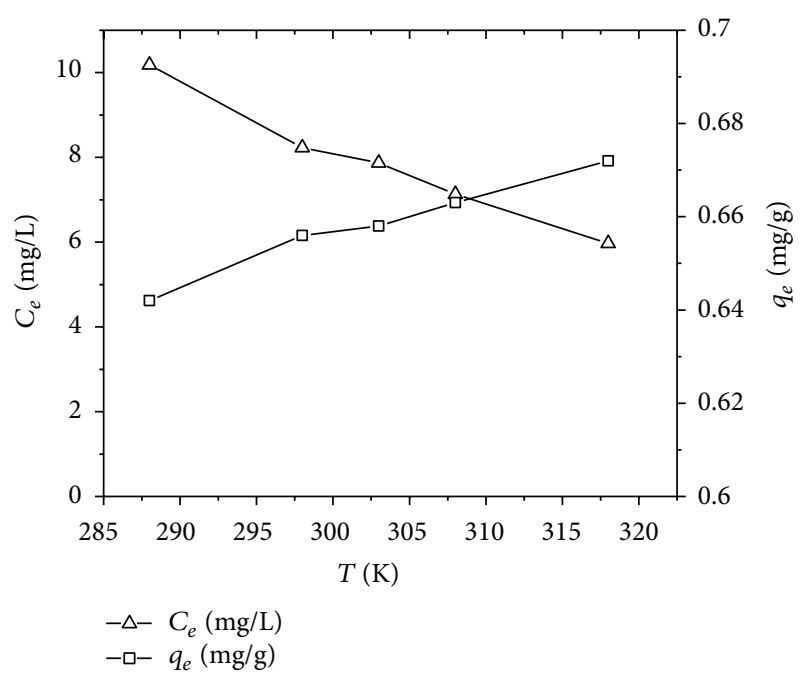

(a)

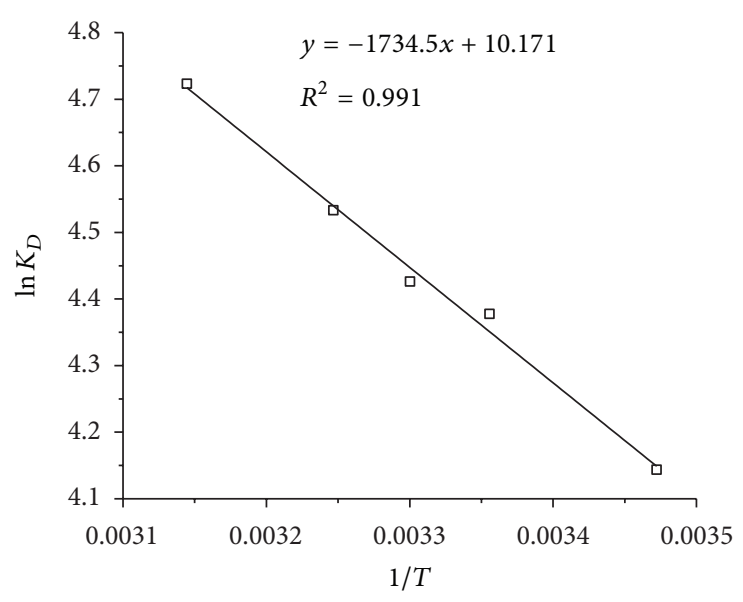

(b)

FIGURE 5: Effect of temperature on phenol adsorption: (a) the equilibrium concentration $\left(C_{e}\right)$ and equilibrium adsorption capacity $\left(q_{e}\right)$ variation; (b) distribution coefficient $\left(K_{D}\right)$ variation.

capacity obviously increased with temperature rise, which indicated that the adsorption of phenol on the granules was not exothermic but endothermic [23]. The increase in temperature supplied more energy to the phenol molecules and more chances for phenol interaction with the active sites at the surface and internal structure of the granules [24]; consequently more phenol was adsorbed. The increase in phenol adsorption capacity of the granules with the increase in temperature was similar to some carbonaceous adsorbents [25].

The influence of temperature on phenol adsorption onto the ceramic granules can be analyzed with thermodynamic parameters including free energy change $\left(\Delta G^{\circ}\right)$, enthalpy $\left(\Delta H^{\circ}\right)$, and entropy $\left(\Delta S^{\circ}\right)$. The relation among the three parameters can be expressed with (3), and $\Delta G^{\circ}$ can be calculated with thermodynamic distribution coefficient $\left(K_{D}\right)$ $((4)$ and $(5))[26,27]$ :

$$
\Delta G^{\circ}=\Delta H^{\circ}-T \Delta S^{\circ}
$$

where $T$ is the temperature,

$$
\Delta G^{\circ}=-R T \ln K_{D}
$$

where $R$ is the universal gas constant $(8.314 \mathrm{~J} /(\mathrm{mol} \mathrm{K}))$, and

$$
K_{D}=\frac{q_{e}}{C_{e}}
$$

where $C_{e}$ and $q_{e}$ are the equilibrium concentration and the equilibrium adsorption capacity with units of $\mathrm{mg} / \mathrm{mL}$ and $\mathrm{mg} / \mathrm{g}$, respectively.

Consequently, (6) can be obtained with the combination of (3) and (4). With the data in Figure 5(a), the thermodynamic parameters of $\Delta H^{\circ}$ and $\Delta S^{\circ}$ were acquired with the slope and intercept of Figure 5(b); then $\Delta G^{\circ}$ was calculated using (3). The values of $\Delta G^{\circ}, \Delta H^{\circ}$, and $\Delta S^{\circ}$ for the adsorption of phenol on the ceramic granules are shown in Table 3:

$$
\ln K_{D}=\frac{\Delta S^{\circ}}{R}-\frac{\Delta H^{\circ}}{R T}
$$

The positive value of $\Delta H^{\circ}$ indicated that the adsorption of phenol was endothermic, which was also supported by the slightly increase of the equilibrium adsorption capacity with temperature rise. The positive value of $\Delta S^{\circ}$ suggested the increase of randomness at liquid/solid interface during phenol adsorption, which was mainly caused by the substitution of water by phenol with larger molecular weight at the interface [28]. The faster move of water molecules from the solid interface to liquid face resulted in the increase of the entropy. The negative free energy changes $\left(\Delta G^{\circ}\right)$ indicated that the adsorption of phenol on the ceramic granules was spontaneous. Moreover, the decrease of $\Delta G^{\circ}$ with temperature showed that the adsorption was more favorable at higher temperatures. As shown in Figure 5(a), the adsorption was more complete at higher temperatures. However, $\Delta G^{\circ}$ only changed from $-9.93 \mathrm{~kJ} / \mathrm{mol}$ to $-12.47 \mathrm{~kJ} / \mathrm{mol}$ with temperature ranging from $288 \mathrm{~K}$ to $318 \mathrm{~K}$, and adsorption capacity also varied slightly with temperature variation. Therefore, the influence of temperature on phenol adsorption was minor compared with that of dosage and contact time. Phenol adsorption on the ceramic granules can be accomplished at normal temperatures.

3.7. Adsorption Isotherm. Adsorption isotherm is usually used to describe the relationship between the equilibrium adsorption capacity and equilibrium concentration under a constant temperature. Langmuir isotherm model (7) and Freundlich isotherm model (8) are usually used to describe the distribution of adsorbates between the liquid phase and the solid phase [29]. The adsorption isotherm of phenol on 


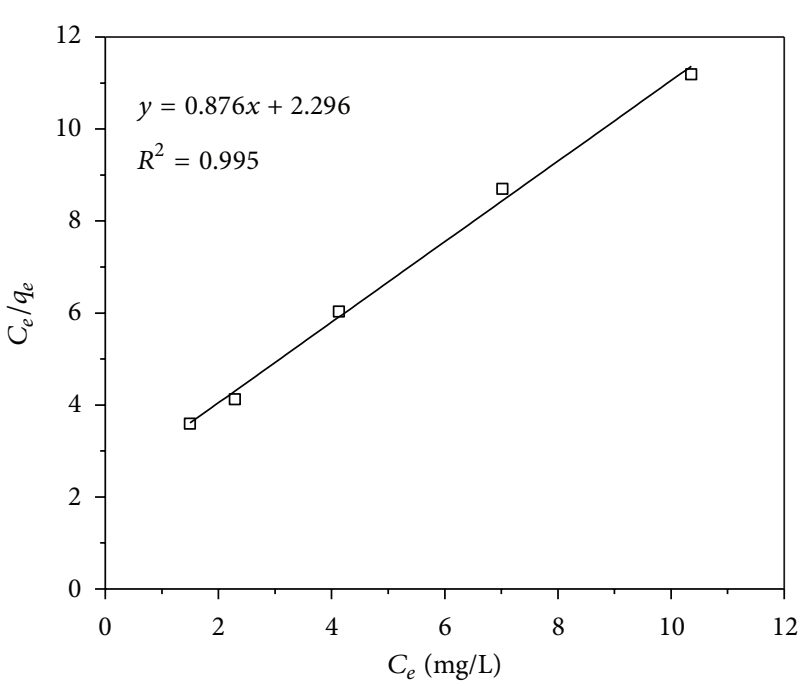

(a)

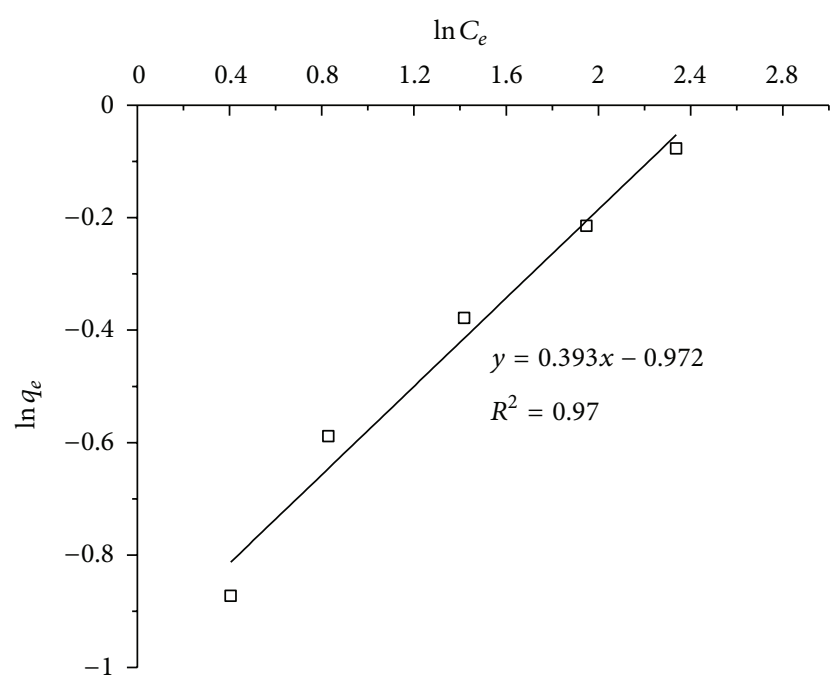

(b)

FIgURE 6: Adsorption isotherm of phenol onto the granules: (a) Langmuir model; (b) Freundlich model.

the ceramic granules was obtained with initial phenol concentration varying from $60 \mathrm{mg} / \mathrm{L}$ to $140 \mathrm{mg} / \mathrm{L}$ and granules dosage of $140 \mathrm{~g} / \mathrm{L}$ at $303 \mathrm{k}$. The adsorption time and initial $\mathrm{pH}$ value were controlled at $90 \mathrm{~min}$ and 7.0, respectively:

$$
\begin{aligned}
\frac{C_{e}}{q_{e}} & =\frac{1}{Q_{m} b}+\frac{C_{e}}{Q_{m}}, \\
q_{e} & =k_{f} C_{e}^{1 / n},
\end{aligned}
$$

where $Q_{m}$ is the adsorption capacity $(\mathrm{mg} / \mathrm{g})$, and $b, k_{f}$, and $n$ are characteristic constants of adsorption. For linearization of the data, the Freundlich equation can be written in the following logarithmic form:

$$
\ln q_{e}=\ln k_{f}+\frac{1}{n} \ln C_{e} .
$$

The linearization of equilibrium data under different initial concentrations showed that the adsorption of phenol on the ceramic granules complied with both Langmuir and Freundlich isotherm model (Figure 6). $Q_{m}$ and $b$ in Langmuir model were calculated to be $1.142 \mathrm{mg} / \mathrm{g}$ and $0.381 \mathrm{~L} / \mathrm{mg}$. $k_{f}$ and $n$ in Freundlich model were estimated to be 0.378 and 2.545 , respectively. Nevertheless, the $R^{2}$ value of Langmuir model was higher than that of Freundlich model, so the Langmuir isotherm model was more appropriate for phenol adsorption on the granules.

3.8. Overall Evaluation and Comparison with Other Adsorbents. This kind of ceramic granules is efficient and convenient to be used in phenol removal from water. After saturation, the granules are easily to be separated from the aqueous solution. There are many studies on phenol removal with powder-activated carbon, fly ash [10], and organobentonite [30]. However, such materials can only work efficiently with the integration of coagulation [31]. In this study, with the ceramic granules' application, there is no need for other disposal steps of coagulation or sedimentation. The adsorption with the granules can be operated under normal temperature and neutral $\mathrm{pH}$ with high efficiency. In the study of Parida and Pradhan [29] with manganese nodule leached residue as adsorbent, the adsorption was almost doubled with temperature increased from $298 \mathrm{~K}$ to $338 \mathrm{~K}$, and phenol was only adsorbed completely at low $\mathrm{pH}$. Alzaydien and Manasreh [32] found that phenol adsorption onto activated phosphate rock was also affected obviously by $\mathrm{pH}$ and temperature. The adsorption capacity reached the highest value at $\mathrm{pH}$ 8.0, whereas it decreased greatly with temperature increase. In this study, the adsorption of phenol onto the ceramic granules is also very fast, and it can reach equilibrium at around $90 \mathrm{~min}$. In the study of Srivastava et al. [9] with bagasse fly ash and activated carbon to remove phenol, the optimum equilibrium time was around $5 \mathrm{~h}$, whereas in a study with zeolitic material made from bagasse fly ash as adsorbent, the adsorption equilibrium time was as long as $10 \mathrm{~h} \mathrm{[33].}$

\section{Conclusions}

The granules mainly made of coal fly ash were abundant with nanosize pores. The specific surface area and porosity reached $130.5 \mathrm{~m}^{2} / \mathrm{g}$ and $60.1 \%$, respectively. $\mathrm{SiO}_{2}, \mathrm{Al}_{2} \mathrm{O}_{3}$, $\mathrm{MgO}, \mathrm{Fe}_{2} \mathrm{O}_{3}, \mathrm{CaO}, \mathrm{K}_{2} \mathrm{O}$, and unburned carbon were the main compositions in the granules. The granules showed high efficiency in phenol adsorption. From solution with initial phenol concentration of $100 \mathrm{mg} / \mathrm{L}$, more than $90 \%$ phenol could be removed with contact time of $90 \mathrm{~min}$ and dosage of $140 \mathrm{~g} / \mathrm{L}$. Although the adsorption of phenol on the granules was endothermic, phenol adsorption on the granules could 
be operated under normal temperature efficiently. Phenol adsorption on the granules complied well with the pseudosecond-order kinetic model and Langmuir isotherm model.

\section{Acknowledgment}

This study is supported by the project of the Priority Academic Program Development of Jiangsu Higher Education Institutions (PAPD).

\section{References}

[1] S. Wang, M. Soudi, L. Li, and Z. H. Zhu, "Coal ash conversion into effective adsorbents for removal of heavy metals and dyes from wastewater," Journal of Hazardous Materials, vol. 133, no. 1-3, pp. 243-251, 2006.

[2] A. Olgun, Y. Erdogan, Y. Ayhan, and B. Zeybek, "Development of ceramic tiles from coal fly ash and tincal ore waste," Ceramics International, vol. 31, no. 1, pp. 153-158, 2005.

[3] A. Singh, R. K. Sharma, and S. B. Agrawal, "Effects of fly ash incorporation on heavy metal accumulation, growth and yield responses of Beta vulgaris plants," Bioresource Technology, vol. 99, no. 15, pp. 7200-7207, 2008.

[4] S. Wang, Q. Ma, and Z. H. Zhu, "Characteristics of coal fly ash and adsorption application," Fuel, vol. 87, no. 15-16, pp. 34693473, 2008.

[5] A. H. Norzilah, A. Fakhru'l-Razi, S. Y. Thomas Choong, and A. Luqman Chuah, "Surface modification effects on CNTs adsorption of methylene blue and phenol," Journal of Nanomaterials, vol. 2011, Article ID 495676, 18 pages, 2011.

[6] M. Sarkar, P. K. Acharya, and B. Bhattacharya, "Modeling the adsorption kinetics of some priority organic pollutants in water from diffusion and activation energy parameters," Journal of Colloid and Interface Science, vol. 266, no. 1, pp. 28-32, 2003.

[7] S. H. Lin and R. S. Juang, "Adsorption of phenol and its derivatives from water using synthetic resins and low-cost natural adsorbents: a review," Journal of Environmental Management, vol. 90, no. 3, pp. 1336-1349, 2009.

[8] R. Aravindhan, J. R. Rao, and B. U. Nair, "Application of a chemically modified green macro alga as a biosorbent for phenol removal," Journal of Environmental Management, vol. 90, no. 5, pp. 1877-1883, 2009.

[9] V. C. Srivastava, M. M. Swamy, I. D. Mall, B. Prasad, and I. M. Mishra, "Adsorptive removal of phenol by bagasse fly ash and activated carbon: equilibrium, kinetics and thermodynamics," Colloids and Surfaces A, vol. 272, no. 1-2, pp. 89-104, 2006.

[10] M. Sarkar and P. K. Acharya, "Use of fly ash for the removal of phenol and its analogues from contaminated water," Waste Management, vol. 26, no. 6, pp. 559-570, 2006.

[11] Z. Jing, Y. Y. Li, S. Cao, and Y. Liu, "Performance of double-layer biofilter packed with coal fly ash ceramic granules in treating highly polluted river water," Bioresource Technology, vol. 120, pp. 212-217, 2012.

[12] G. Lu, G. Q. Lu, and Z. M. Xiao, "Mechanical properties of porous materials," Journal of Porous Materials, vol. 6, no. 4, pp. 359-368, 1999.

[13] Y. Liu, L. Zheng, X. Li, and S. Xie, "SEM/EDS and XRD characterization of raw and washed MSWI fly ash sintered at different temperatures," Journal of Hazardous Materials, vol. 162, no. 1, pp. 161-173, 2009.
[14] C. Kang, Y. Wang, R. Li et al., "A modified spectrophotometric method for the determination of trace amounts of phenol in water," Microchemical Journal, vol. 64, no. 2, pp. 161-171, 2000.

[15] Y. Xue, S. Wu, H. Hou, and J. Zha, "Experimental investigation of basic oxygen furnace slag used as aggregate in asphalt mixture," Journal of Hazardous Materials, vol. 138, no. 2, pp. 261268, 2006.

[16] B. G. Kutchko and A. G. Kim, "Fly ash characterization by SEMEDS," Fuel, vol. 85, no. 17-18, pp. 2537-2544, 2006.

[17] M. Inagaki, S. Kobayashi, F. Kojin, N. Tanaka, T. Morishita, and B. Tryba, "Pore structure of carbons coated on ceramic particles," Carbon, vol. 42, no. 15, pp. 3153-3158, 2004.

[18] R. M. Prasad, G. Mera, K. Morita et al., “Thermal decomposition of carbon-rich polymer-derived silicon carbonitrides leading to ceramics with high specific surface area and tunable micro- and mesoporosity," Journal of the European Ceramic Society, vol. 32, no. 2, pp. 477-484, 2012.

[19] R. Tailor, B. Shah, and A. Shah, "Sorptive removal of phenol by zeolitic bagasse fly ash: equilibrium, kinetics, and column studies," Journal of Chemical \& Engineering Data, vol. 57, no. 5, pp. 1437-1448, 2012.

[20] R. L. Tseng, K. T. Wu, F. C. Wu, and R. S. Juang, "Kinetic studies on the adsorption of phenol, 4-chlorophenol, and 2,4dichlorophenol from water using activated carbons," Journal of Environmental Management, vol. 91, no. 11, pp. 2208-2214, 2010.

[21] A. Bhatnagar and M. Sillanpää, "Utilization of agro-industrial and municipal waste materials as potential adsorbents for water treatment-A review," Chemical Engineering Journal, vol. 157, no. 2-3, pp. 277-296, 2010.

[22] S. Wang and $\mathrm{H}$. Wu, "Environmental-benign utilisation of fly ash as low-cost adsorbents," Journal of Hazardous Materials, vol. 136, no. 3, pp. 482-501, 2006.

[23] H. L. Wang and W. F. Jiang, "Adsorption of Dinitro Butyl Phenol (DNBP) from aqueous solutions by fly ash," Industrial and Engineering Chemistry Research, vol. 46, no. 16, pp. 5405-5411, 2007.

[24] M. A. Hararah, K. A. Ibrahim, A. H. Al-Muhtaseb, R. I. Yousef, A. Abu-Surrah, and A. Qatatsheh, "Removal of phenol from aqueous solutions by adsorption onto polymeric adsorbents," Journal of Applied Polymer Science, vol. 117, no. 4, pp. 1908-1913, 2010.

[25] F. Banat, S. Al-Asheh, and L. Al-Makhadmeh, "Utilization of raw and activated date pits for the removal of phenol from aqueous solutions," Chemical Engineering and Technology, vol. 27, no. 1, pp. 80-86, 2004.

[26] A. A. Khan and R. P. Singh, "Adsorption thermodynamics of carbofuran on Sn (IV) arsenosilicate in $\mathrm{H}^{+}, \mathrm{Na}^{+}$and $\mathrm{Ca}^{2+}$ forms," Colloids and Surfaces, vol. 24, no. 1, pp. 33-42, 1987.

[27] H. B. Senturk, D. Ozdes, A. Gundogdu, C. Duran, and M. Soylak, "Removal of phenol from aqueous solutions by adsorption onto organomodified Tirebolu bentonite: equilibrium, kinetic and thermodynamic study," Journal of Hazardous Materials, vol. 172, no. 1, pp. 353-362, 2009.

[28] V. Gökmen and A. Serpen, "Equilibrium and kinetic studies on the adsorption of dark colored compounds from apple juice using adsorbent resin," Journal of Food Engineering, vol. 53, no. 3, pp. 221-227, 2002.

[29] K. M. Parida and A. C. Pradhan, "Removal of phenolic compounds from aqueous solutions by adsorption onto manganese nodule leached residue," Journal of Hazardous Materials, vol. 173, no. 1-3, pp. 758-764, 2010. 
[30] Y. H. Shen, "Removal of phenol from water by adsorptionflocculation using organobentonite," Water Research, vol. 36, no. 5, pp. 1107-1114, 2002.

[31] M. Tomaszewska, S. Mozia, and A. W. Morawski, "Removal of organic matter by coagulation enhanced with adsorption on PAC," Desalination, vol. 161, no. 1, pp. 79-87, 2004.

[32] A. S. Alzaydien and W. Manasreh, "Equilibrium, kinetic and thermodynamic studies on the adsorption of phenol onto activated phosphate rock," International Journal of Physical Sciences, vol. 4, no. 4, pp. 172-181, 2009.

[33] B. Shah, R. Tailor, and A. Shah, "Adaptation of bagasse fly ash, a sugar industry solid waste into zeolitic material for the uptake of phenol," Environmental Progress \& Sustainable Energy, vol. 30, no. 3, pp. 358-367, 2011. 

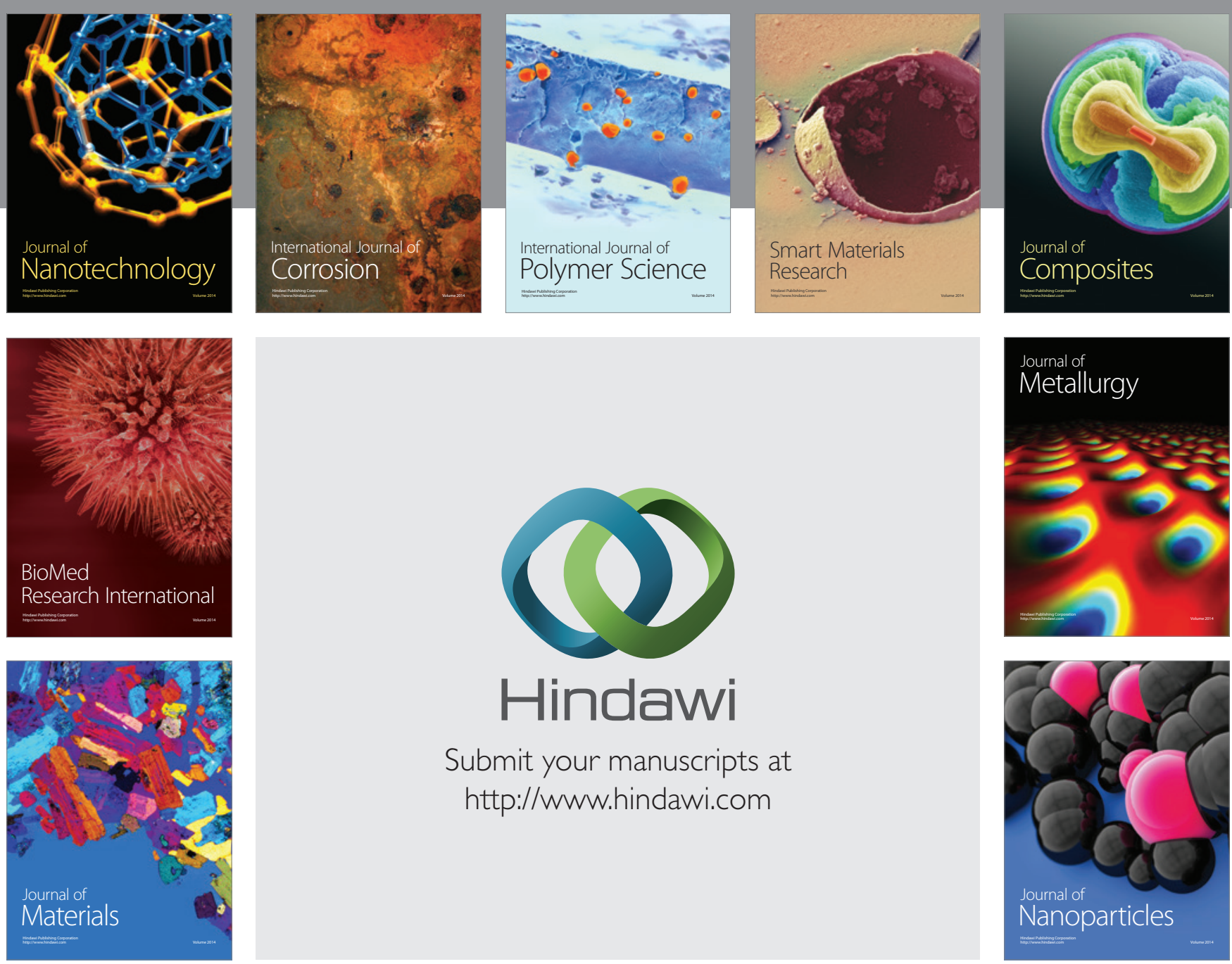

Submit your manuscripts at http://www.hindawi.com
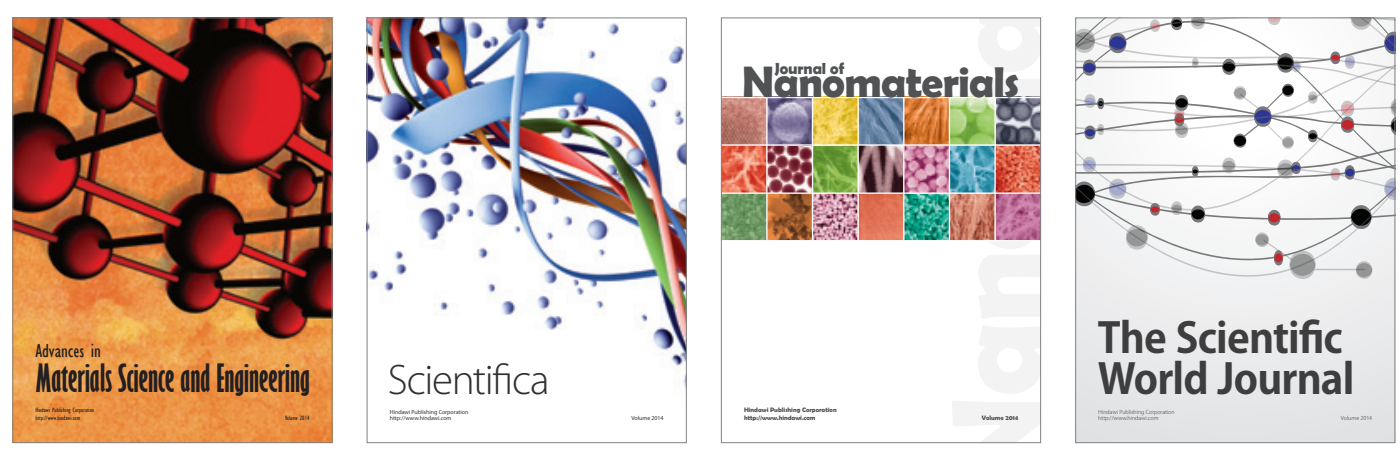

\section{The Scientific World Journal}
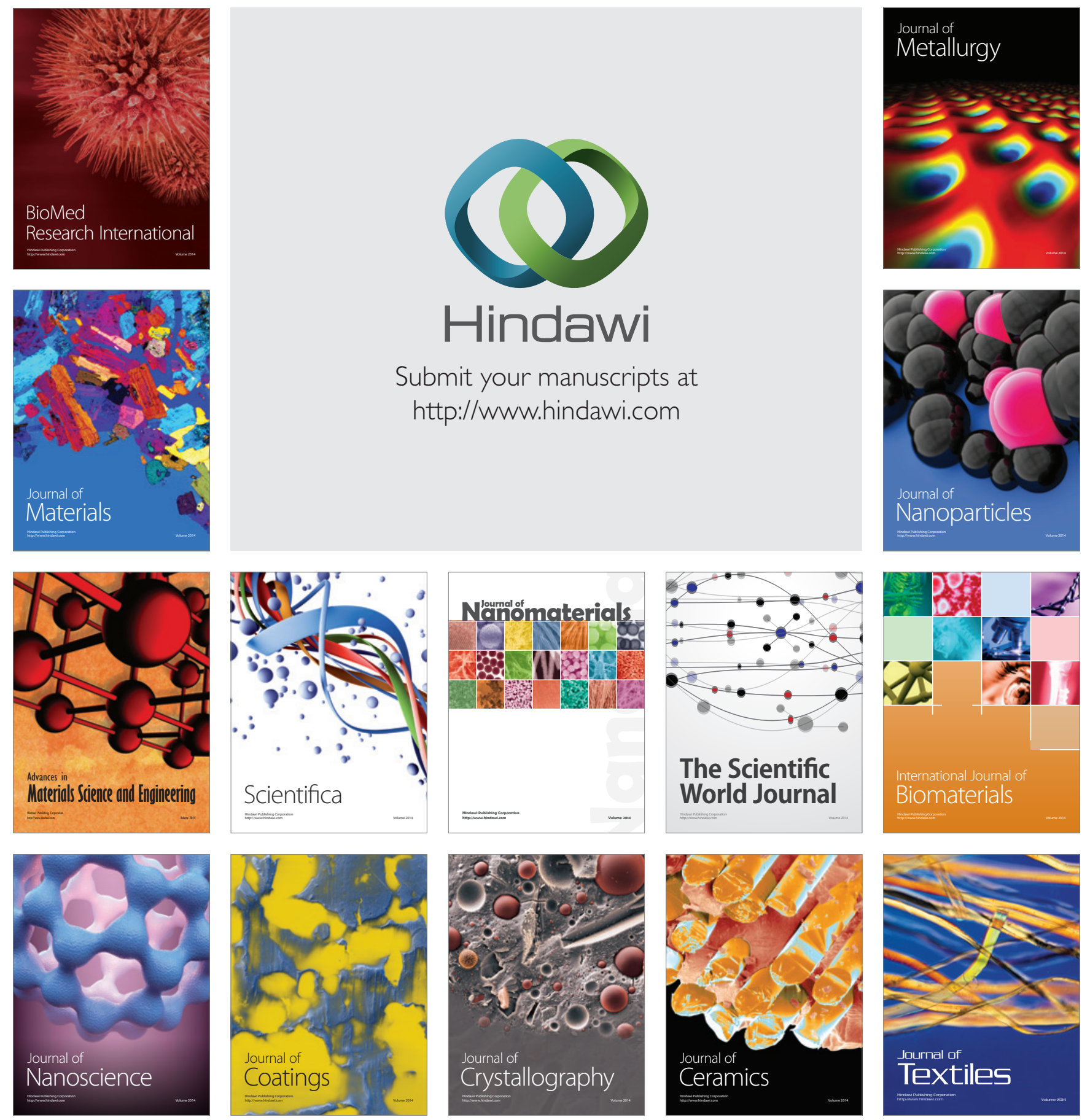